the fifth century B.c.), exemplifies the literary parallelism which marks the average Hebrew poetical composition, and indeed much resembles a passage in the Canticles:

\author{
Waking and sleeping he sought her, \\ Sought her but found her not; \\ Waking and sleeping he cherished her, \\ Long, long he thought upon her, \\ Turning from side to side.
}

The Chinese, with their monosyllabic words, and mosaic-like character blocks, have developed their scheme of literary parallelism to an extreme of refinement. In one of the best poems of China, by the painter-poet Wang Wei (d. $75^{\circ}$ A.D.), the five-word lines translate almost literally thus :

Declining day-beams light each rustic home, Along the lanes the flocks returning come; The aged men their herdsman sons await, And staff-supported stand beside the gate;
The wild birds fly o'er fields of ripening corn, The silkworms sleep on mulberry twigs half-shorn; With shouldered hoe the farmers homeward stride, To spend in social chat the eventide.

The general scheme of parallelism in the whole will be noted, but in the original of lines five and six there is also a complete parallelism of character to character; as well as the real antithesis of wild wings in motion and of worms in repose, and the further apparent antithesis of fulness and scarcity (crops and tree-twigs), with the actual blending of felicitous thought. This is fine art, such as is prized in mottoes for doorways and guest-rooms. And not a few Hebrew couplets are found to have a basis of very exact parallelism. Thus Ps I $26^{5.6}$ might be read in terser form, as though in Chinese :

Going forth, sorrowing, scattering good seed; Coming home, rejoicing, gathering much grain.

\title{
Jfuffiment of the Eaw.
}

\author{
By the Rev. W. T. Whitiey, M.A., LL.D., Preston.
}

OUR Lord announced that $\mathrm{He}$ did not come to destroy the Law and the Prophets, but to fulfil. What exactly did He mean?

To 'fulfil the prophets' is a phrase used extensively by Matthew, who evidently meant, To match prediction by accomplishment. The other half of the phrase might by analogy be understood, To match an order by obedience. But it has received much less attention, and lately it has been quoted in very illegitimate connections, with untenable senses put on it, to support positions open to grave challenge. Because of the practical proposals made, it seems desirable to examine the Biblical basis of these proposals, and to inquire rigorously into the meaning of the phrase, To fulfil the Law.

The Law in question is the Jewish Law, and nothing else. Our Lord's horizon in most of His prophetic ministry was national, and Matthew emphasizes this aspect of it. The Sermon on the Mount was spoken to Jews, and they attached very definite meanings to the terms "Law" and "Prophets."

The inquiry therefore is as to the verb Fulfil, which is used ninety times in the N.T., while a noun derived from it, generally translated Fulness, occurs seventeen times. We may compare these passages and derive from them the various meanings of the Greek verb, then test which meaning best suits the present passage. The result may be checked by a wider induction from the N.T. as to the actual relation of our Lord to the Law, and by another inquiry as to the present status of the Law.

\section{The Usage of the Word Fulfil.}

To Fulfil is literally to Fill full; as a valley is levelled up with earth and stones from a mountain, for a highway; as a net is filled with fish, or a measure with corn; as a hole in a coat is filled with a patch, or baskets are filled with fragments of bread and fish. By a slight extension from material things, as a house is pervaded with the presence of the Spirit, or Jerusalem with teaching about the Lord.

The literal meaning is rare, and it is the derived meanings that need to be examined. We may pass instances of the active voice, men being filled with joy, sorrow, knowledge, comfort, unrighteousness; and may study passages speaking of some object being fulfilled. These fall into three groups, which are typically Lucan, Johannine, Pauline. 
Luke habitually uses the word with the general sense, Complete and End. Four times he speaks of times being ended, Lk $2 \mathrm{I}^{24}$, Ac $7^{23.30} 9^{23}$; once of sayings, $\mathrm{Lk} 7^{1}$; once of events, $\mathrm{Ac} \mathrm{I} 9^{21}$; four times of a piece of service, $\operatorname{Lk} 9^{31}$, Ac $\mathrm{I}^{25}$ I $3^{25} \mathrm{I} 4^{2 n}$. The same sense is found also at $\mathrm{Mk} \mathrm{I}{ }^{15}, \mathrm{Jn} 7^{s}$. The corresponding noun, never used by Luke, signifies a Completed number, Ro I I $^{12.25}$, a Completed time or times, Gal $4^{4}, \mathrm{Eph} \mathrm{r}^{10}$.

In the Fourth Gospel we find the phrase, 'Joy is fulfilled' $\left(3^{29}\right.$ I $5^{11}$ I $6^{24}$ I $\left.7^{13}\right)$; and the same idea is in $\mathrm{Ph}_{2}^{2} 4^{19}, 2 \mathrm{Th} \mathrm{r}^{11}$, though in two of these cases the verb is active. The sense here is to Complete and Satisfy. The derived noun has a kindred meaning of Satisfying Completeness in Jn $1^{16}$, Col $1^{19} 2^{9}$, Eph $1^{23} 3^{19} 4^{13}$, Ro I $5^{29}$.

The way Paul generally uses the verb is closely akin to this, to Complete and Satisfy, to Complete and Discharge a duty. At Ro $15^{19}$ he says he has discharged his duty of preaching throughout a district; at $\mathrm{Col} 4^{17}$ he bids Archippus discharge his duty; at Col $\mathrm{x}^{25}$ he declares his commission to be the complete carrying out of God's word. Thrice he deals with the very idea before us, Fulfiling the Law; at Gal $5^{15}$ the meaning is that the whole Law is completely carried out in one maxim ; at Ro $8^{4}$, the requirement of the Law may be completely discharged in us; at Ro ${ }_{1} 3^{\mathrm{S}}$, he that loves his neighbour has completely obeyed the Law. And the noun expresses the same thouglit, $\operatorname{Ro}_{1} 3^{10}$, Love is the satisfaction of the Law.

Outside the first Gospel we thus find simply two shades of meaning: Complete and End, Complete and Satisfy. We have now to test which is more suitable here.

- The verb occurs in Mathew seventeen times, twice meaning literally, Fill. Thirteen instances refer to the accomplishment of predictions, more akin to the second shade. There remain two cases, Fulfil all righteousness, Fulfil the Law ; and presumably in kindred phrases the meaning is the same. Our Lord certainly did not mean that $\mathrm{He}$ was bringing righteousness to an end, we therefore take the second meaning. He told John that He had come to satisfy the requirements of righteousness; He told the people that $\mathrm{He}$ had come to satisfy the Law.

Thus we are guided to the sense, Respect, Discharge, Obey completely. This is arrived at by strict induction from every passage in the N.T. where the verb and its derived noun occur.
In the LXX the same meaning is found at Ps $20^{4.5}$.

It is surprising to find this meaning summarily rejected by Hort (Jut. Christianity, I 5): "TVe may safely neglect the meaning which perhaps comes first to mind, that of personal obedience or performance, as we speak of the fulfilment of an injunction.' No reason is vouchsafed for this curt dismissal, and the next sentence is more astonishing: 'Its true meaning answers much more exactly to that destroying or undoing to which it is here formally opposed.' 'That is to say, our Lord was drawing a distinction without a difference! and was explaining away a fear that was well founded! Presently the text is thus interpreted (page I 8 ): The Law 'remained binding within its own limits, but it was to be filled out and deepened by a new spirit, the prohibition of murder, for instance, being fulfilled by the prohibition of anger against a brother.' To this explanation, which carries with it a train of implications from which we dissent, we oppose the simple fact that the word Fulfil never bears any such meaning elsewhere.

The meaning at which we have arrived is fully accepted by Archdeacon Allen in his commentary; to Reaffirm and Carry out in detail. It agrees with the other part of the sentence, which will then mean : I am come to match the orders of the Law and the predictions of the Prophets by punctilious performance. But Mr. Allen also notes, what is often overlooked, that these verses do not explain the discussion of the Law which follows. Perhaps Hort's refusal to accept what he owned to be the obvious meaning, was due to the tacit idea that $v{ }^{17}$ is a text, vv. ${ }^{21-43}$ are illustrations of the text. Another connexion avoids the difficulty, and shows a progress of thought, as to the Law, and as to the authority of Christ. 'I am not here to repeal the Law as lawgiver, nor to defy it as rebel, but to obey it as under law. Till $I$ have obeyed it, it stands in all respects. As lawgiver, I raise for the future a higher standard of conduct; the Law is inadequate in some respects, and absolutely bad in others. My comprehensive maxim is, Do as you would be done by. This contains everything good in the Law and in the teaching of the Prophets. To appreciate it is easy, to perform it is needful ; for I am more than obedient to the Law, I am the lawgiver.'

Such a movement of thought is coherent in itself, and is congruous with other teaching. It removes 
all temptation to read back into the word Fulfil various shades of meaning suggested by the drastic criticisms of the Law in the rest of the chapter. It leaves us free to adhere to the meaning which 'comes first to mind,' and which contents such lexicographers as Cremer and Thayer. But it raises theological questions which are too often evaded by understanding the word otherwise. And to these we must advance.

\section{Orr Lord's Obedience to the Law.}

The conclusion from usage may now be confirmed from an examination of what our Lord actually did in relation to the Law. He obeyed it in every respect, and was careful to impress upon others their habitual disobedience and $\mathrm{His}$ obedience.

He told the lepers whom $\mathrm{He}$ healed, what the Law required of them. He appealed to it in argument repeatedly, eren while asserting that no one really kept it ( $\mathrm{Jn} 7^{19}$ ). More than once $\mathrm{He}$ invited any accusation that $\mathrm{He}$ was breaking it, and when murmurs were heard as to $\mathrm{His}$ disregard of the Sabbath, He defended Himself not by repudiating the Sabbath-law, but by quoting precedents and arguing that $\mathrm{He}$ was still keeping it, in spirit and in letter. On one dramatic occasion, when the death-penalty prescribed in the Law was not consonant with public feeling, and the scribes tried to entrap Him into contradicting it, He overcame the difficulty by inducing them to waive their accusation. $\mathrm{He}$ defended another precept as to sexual morality, and even showed that $\mathrm{He}$ was prepared to go further. And when the fictions of the lawyers had contrived an evasion of another precept, $\mathrm{He}$ plainly accused them of rejecting the commandment of God. Such incidents illustrate how they were destroying the Law, He was upholding it.

On His last evening with the disciples, $\mathrm{He}$ reflected that $\mathrm{He}$ had accomplished what $\mathrm{He}$ was entrusted with; this of course surveys much more, but it includes contentment with having kept the Law. Next morning one charge against Him was that by their Law He ought to die. If indeed $\mathrm{He}$ had 'made Himself' the Son of God, $\mathrm{He}$ would not have denied the application of the Law. But His closing breath reiterated the claim of the supper room, and announced that it was finished. Again, whatever more was finished, $\mathrm{H}$ is life of obedience to the Law was over. Born under the
Law, He had redeemed those who were under the Law. All things were accomplished; the Law had not been destroyed by $\mathrm{Him}$, it had been completely carried out and satisfied.

Thus the events in our Lord's life confirm our interpretation of $\mathrm{His}$ utterance: $\mathrm{He}$ said that $\mathrm{He}$ would obey the Law; He did. But another question soon forced itself on the attention of $\mathrm{His}$ followers, who had heard such an utterance as 'The Law and the Prophets until John.' What was the binding force of the Law after His obedience? All was accomplished; did it hold any longer in any jot or tittle?

\section{Our Lord's Ending of the Law.}

We have seen that the word Fulfil has as one shade of meaning, To Complete and Finish; does that shade also attach to our Lord's utterance? When $\mathrm{He}$ obeyed it, did $\mathrm{He}$ thereby exhaust it? Our English laws as to contracts easily suggest as much. A contract may be found very onerous, and a man may be tempted to repudiate it or to declare himself bankrupt rather than fulfil his side; but if he does honourably fulfil it, and the other party fulfils his side, then the contract has no further binding force: being fulfilled, it cannot be enforced again. The question is of real and present importance; is the Law still binding on a Jew?

In the Acts and the Epistles we can see this question being raised, and successive answers being given. The earliest converts from the Jews still frequented the temple, but the drift of the new teaching was such that Stephen was charged with speaking against the Law, and with asserting that Jesus would change the customs of Moses. We can trace the exact process when Peter was convinced that he was to do something that he and his hearers knew was against the Law, when he was called to account, when he vindicated his action (Ac $\mathrm{IO}^{29} \mathrm{y} \mathrm{I}^{2.17}$.18). He was presently persuaded that this was no isolated case, but a precedent (Gal 211-14). The next step was taken when an attempt was made to impose the Law upon Gentile converts, and the attempt was decisively defeated (Ac I 5 ). The debate shows that few had grasped as yet that the Law was obsolete even for Jews, but it shows Peter taking up a position more advanced than before, declaring it an unbearable yoke.

Opinion ripened when troubles arose in other 
Gentile churches; Paul argued out what he had summarily announced (Ac $\mathrm{I}_{3}{ }^{39}$ ), that no one could achieve salvation by keeping the Law. As he unfolded his argument to the Ronans, he arrived at the conclusion, not only that the Law was useless as a means of salvation, but that Christians are dead to the Law, discharged from it (Ro $7^{4,6}$ ). He was careful to say that the Law was good; he went as far as to say that he was establishing it rather than voiding it; but the course of the argument shows that he was establishing it on a very new footing. Its value henceforth consisted, as it had been with the Psalmist, in convincing a man of his sin and impotence (Ro $7^{i .21}$ ); and in driving him in despair to Christ for salvation (Ro $7^{24-25}$, Gal $\left.3^{2-1}\right)$. As a means of salvation it is ineffective, as a Law it is not binding on a Christian (Ro $8^{3.2}$ ). Christ is the end of the Law ( $\mathrm{Ro} \mathrm{IO}{ }^{+}$); $\mathrm{He}$ is the climax to whom it was leading up; $\mathrm{He}$ brings it to an end.

Paul developed this doctrine at much length, and in his later writings it appears incidentally, as axiomatic. What divided Jew from Gentile? the Law : Christ's work was to reconcile Jew and Gentile, therefore $\mathrm{He}$ broke down the wall, abolishing the Law (Eph $\left.2^{15}\right)$. The bond written in ordinances, He has taken out of the way and nailed it to the cross $\left(\mathrm{Col}{ }^{14}\right)$. The Law was made for sinners, and is good for them ; but it is not meant for a man justified by Christ ( $1 \mathrm{Ti} \mathrm{I}^{\text {s. }}$ ).

Cognate doctrine was taught in other quarters. James contented himself with the negative side and did not explicitly unfold the positive. When he expounded what is pure religion, he did not mention the Law ; rather he referred to the perfect law of liberty, the royal law: and this, though he expressed it in a sentence from the Law, is not that Mosaic Law. Concerning that, he said briefly that a breach of it in any one point is as bad as a general disregard-whence it follows that it may as well be neglected altogether. $\mathrm{He}$ reasserted that the law by which we shall be judged, is a law of liberty $\left(2^{\mathbf{5}-12}\right)$. Yet he forbade to speak evil of the Law $\left(4^{11}\right)$; the point is that while it is good, it is no longer put forward as binding. Meanwhile, as regards Gentiles, James had taken the lead in dictating the letter which expressly exonerated them from any obligation to it.

Many Hebrews were reluctant to abandon their venerable code, and it became necessary to re- iterate that the Law was expired. Paul had dropped the hint that it was only parenthetical, till Christ (Gal $\left.3^{17}{ }^{19}\right)$. This was now developed on a new side, illustrations being taken from the ritual side rather than the ethical. The argument ran substantially thus: The Law confined the priesthood to the sons of Aaron, yet a psalmist contemplated another priesthood on the lines of Melchizedek; this involved a change of the Law ( $\left.\mathrm{He} 7^{12}\right)$. The priesthood made nothing perfect; this fact revealed that the Law made nothing perfect, that it was weak and unprofitable; the Psalmist foresaw a time when it would be annulled, indeed, the oath he records virtually annulled it at once; $\left(7^{18.19 .28}\right)$. Jeremiah saw that the first Covenant, which was the foundation of the whole Law, was faulty, and he predicted a new one; that prediction deprived the Law of its title to respect, showing it to be obsolescent (8). As for the details of ritual in the Law, meats and drinks and ablutions, with the gifts and sacrifices, they were mere temporary ordinances, quite useless to satisfy the conscience $\left(9^{3 \cdot 10}\right)$. Ceaseless shedding of blood, and occasional sprinkling of ashes, might suit a material tabernacle; but such things were only shadows of realities, and needed to be reiterated because they effected nothing except keeping the conscience in a turmoil at their obvious insufficiency. Another voice repudiated the whole system, and offered in its place the doing of God's will. This is the essence of Christ's work, taking away the mere Law of Moses, to establish Inward Obedience ( $\mathrm{r}^{\mathrm{l}-1 \mathrm{~s} .2 \mathrm{2}}$ ). To shrink back from this to the shelter of the Law, is to displease God, as the prophet saw; it is really to court perdition (10 ${ }^{38.39}$ ).

This pronouncement was unmistakable. Henceforth no one could fancy that any:Christian was bound to keep the Law; ethically it was behind the times, ritually it was external and slightly absurd.

In the writings of John, the Law is mentioned by him just once, as a foil: "What did Moses give? The Law! What did Jesus Christ bring? Grace and truth.' His Epistles ignore it entirely, and emphasize as the all-sufficient rule of conduct the one sentence singled out by the Lord, which had won previous endorsement: 'Love one another.'

This review of apostolic teaching as to the Law illustrates the meaning attached here to our Lord's words. He came to 'fulfil' it. Fulfilling is not expanding it into a thing of beauty, bringing it to 
fulness and completion, so as to inaugurate a new era of usefulness for it. No apostle takes that view of it. Fulfilling is, primarily, obeying it, and secondarily, bringing it to an end. Its chief value had been to educate a longing for a Saviour, while incidentally it had reflected something of Christ before His coming, as the Alpine peak catches the rays before the sun shines into the valleys. Now that the Saviour is come, and we dwell in the light of the sun of righteousness, what need of any childish toying with a mirror?

\section{Two Applications of the Doctrine.}

The early Church grasped this fully. While appeal was made to the O.T. in many ways, so that this assumed a position for all Christians quite unlike any other literature, there was deliberate and repeated repudiation of the Law as binding. Ignatius warned two churches against Judaizing; Justin discussed the matter with Trypho at some length; Aristides and others were at pains to dissociate Christians from Jews in the eyes of the world at large. But as the Jewish Christians were outnumbered by Gentile, were isolated and forgotten, other currents began to run. The positions of 'Barnabas' and Marcion provoked a reaction, the antithesis was no longer so clear, and within three centuries a new legalism arose. It is needless to mention all the errors which from time to time have been buttressed by false ideas as to the Law; but there are two modern misconceptions which deserve to be pointed out, that it may be seen how untenable they are when the words of our Lord are rightly understood.

One is as to conduct. Modern Jews have classified their Law into various sections: Sacrificial, Ceremonial, Political, Moral. The Sacrificial and Political precepts they hold to be in abeyance because they have no temple and no national existence; the Ceremonial and the Moral they consider still obligatory. With much less logic, some Christians cast away also the Ceremonial, but look fondly on the Moral, and they especially revere the Ten Commandments.

To this course there are many objections. Those commandments are plainly prefaced: 'I Jehovah am thy God, who brought thee out of the land of Egypt.' Jehovah did not bring us Britons out of Egypt; and this preface warns us that the commandments were for another people, as much as the Code of Hammurabi or of Confucius.
Again, those commandments are part, and only part, of a far more extensive code, whose first instalment covers $E_{x} 20-23$. We have no right to take part and neglect the rest of this code; in its final form as known in our Lord's day and to us, it emphatically presents itself as one complete whole. Repeatedly we are warned against picking out portions; if we touch any, we are debtors to keep the whole Law. Still less are we at liberty to modify ; the only consistent Christians here are the Seventh-day Baptists, who take the Fourth Commandment quite simply and obey it literally. Again, those commandments are seriously inadequate, and were exposed as such by our Lord. They forbid murder but not anger, adultery but not lascivious words, false evidence but not lying. In the light of $\mathrm{His}$ teaching we see that they are mainly negative; they offer no hint as to courtesy, humility, mercy, which are set in the forefront by Him. As a code of conduct, the Law is defective, redundant, misleading; it is far inferior to the one rule, 'Love one another.'

There is another and newer misconception. Dr. Farquhar has recently studied the relationship of Christianity to Hinduism (I.R.M., July I 9 I 4 ), and he quotes this saying of our Lord as the key to the situation. But when he speaks of the conception of Fulfilment, he interprets it differently. 'In most cases $\mathrm{He}$ fulfils by universalizing a narrow precept, or moralizing an external command.' It has already been pointed out that $\mathrm{He}$ is not fulfilling in the cases cited ( $\mathrm{Mt} 5^{21-44}$ ), $\mathrm{He}$ is criticizing adversely. Much more to the point is the recognition that 'there is another group of cases in which, while the moralizing process is very prominent, there is also the dissolution of an old institution. . . . In all these cases the change is so overturning that the idea of completion scarcely seems to fit well.' It certainly does not, and we have shown that this is a different thought. Unfortunately Dr. Farquhar reads back this thought into the word Fulfil, and then, with the wrong idea that Christ made the Law blossom out into Christianity, he draws his inferences.

He turns to India, and argues that Christ can make Hinduism also blossom out into Christianity. In this reasoning there are two fallacies. Our Lord was speaking of the Jewish Law, not of Hinduism at all: what $\mathrm{He}$ could do for the one, He never promised for the other; the one was God's careful preparation in one chosen nation until the fuiness 
of time came, and there is nothing beyond a general statement that God has not left Himself without witness in any nation, to encourage the thought that a similar preparation has been made in other great religious systems. The second fallacy is that with which this paper is concerned. He did not say of the Law that He came to make it bloom out into perfection, but that $\mathrm{He}$ came to obey it. Whether or no He meant that $\mathrm{He}$ came to end it, $\mathrm{He}$ really did so, and the apostles taught that explicitly.

Dr. Farquhar's practical proposals have no scriptural support here, and his projects show the dangers that arise when we forget the elementary process of examining what a word means.

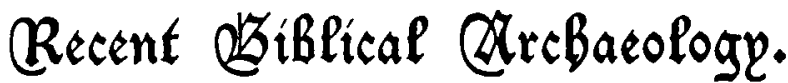

\author{
By the Rev. A. H. Sayce, D.D., LL.D., D.Litt., Professor of Assyriology \\ IN THE UNIVERSiTY OF OXFORD.
}

\section{¿he IFittiter. ${ }^{1}$}

THE Hittites have fallen into good hands. They have now found a historian in the most distinguished historical scholar of Germany, Professor Eduard Meyer, who has just published an account of them and their monuments, which is at once clear, compact, and thorough. It falls into two parts, the first of these being intended for the general public, while the second part contains an exhaustive list of references together with a mass of scientific details, all brought up to date. There are numerous illustrations, moreover, which have been selected with remarkable skill.

That the work should have been entrusted to Professor Eduard Meyer is peculiarly appropriate. J.t was an article of his that first drew my attention to the Hittite monuments years ago, and it was he who first welcomed and accepted my discovery of the Hittite empire. To those who remember the controversies of the early eighties, the universal acceptance to-day of the views which I then propounded will seem somewhat astonishing.

But before going further I have to make a confession. While the learned world has come over to my historical theories and combinations, I have myself been forced by the decipherment of the inscriptions to modify them in one important point. Professor Meyer's book represents my historical belief up to two or three years ago; I have now been compelled to change it. Instead of one Hittite empire, with its capital at Boghaz-Keui, north of the Halys, there were two empires, the second of which rose on the ruins of the first. This second empire was the

\footnotetext{
${ }^{1}$ Reich und Kultur der Chetiler. By Eduard Meyer. Berlin, rgr 4 .
}

Cilician empire of Solinus, which was founded by the Moschians-not by the Hittites proper-about B.C. I 200 , and had its main centre at Tyana. It is to this second empire that the hieroglyphic inscriptions belong which testify to its spread from Lydia in the west to Carchemish in the east, and in which Sandes or Sandakos appears as the national god in place of Tesub. Most of the monuments, accordingly, which we have regarded as evidence of the existence of the earlier empire really bear witness, not to the Hittites of Boghaz-Keui, but to the Moschian Hittites of Tyana. Indeed, it is probable that the same Moschians formed part of the host of northern barbarians, as the Egyptians called them, who destroyed the earlier Hittite empire and swept over the civilized world as far as the borders of Egypt. Chushan-rish-athaim of Naharaim would have been one of their kings.

I can, therefore, no longer regard many of the monuments figured in Professor Meyer's book, as well as in other works on the Hittites, including my own, as connected with the empire whose history is now being recovered from the cuneiform tablets of Boghaz-Keui. It is true that the Moschians belonged to the same racial stock as the Hittites of Boghaz-Keui, and the name Hittite occasionally appears in their inscriptions, but their language was not the same as that of Boghaz-Keui and they called themselves Moschians and Cilicians rather than Hittites. Nor were they governed by an autocratic monarchy like the Hittites of the first empire; their government was theocratic, and the numerous kinglets were under the control of a high priest. The Hittite hieroglyphics, however, were used at Boghaz-Keui contemporaneously with the cuneiform characters, but whether the 